Article

\title{
Investigating the Sustainability Performance of PPP-Type Infrastructure Projects: A Case of China
}

\author{
Shengqin Zheng, Ke Xu* ${ }^{*}$, Qing He *, Shaoze Fang and Lin Zhang $(\mathbb{D}$ \\ School of Management Engineering, Shandong Jianzhu University, Jinan 250101, China; \\ zhshqin@sdjzu.edu.cn (S.Z.); fangshaoze@126.com (S.F.); zhanglin2007@sdjzu.edu.cn (L.Z.) \\ * Correspondence: xukeooop@163.com (K.X.); heqingzdsl@163.com (Q.H.); Tel.: +86-186-6895-8630 (K.X.)
}

Received: 9 October 2018; Accepted: 8 November 2018; Published: 12 November 2018

\begin{abstract}
In China, the demand for public infrastructure projects is high due to the acceleration of urbanization and the rapid growth of the economy in recent years. Infrastructures are mainly large scale, so local governments have difficulty in independently completing financing work. In this context, public sectors often seek cooperation from private sectors, in which public-private partnership (PPP) is increasingly common. Although numerous studies have concentrated on sustainable development, the unsustainability performances of infrastructures are often reported on various media. Furthermore, studies on the sustainability performances of PPP-type infrastructure (PTI) projects are few from the perspective of private sectors' behaviors. In this study, we adopted the modified theory of planned behavior and the structure equation model and conducted a questionnaire survey with 258 respondents for analyzing the sustainable behaviors of private sectors. Results indicated that behavioral attitude, perceived behavioral control, and subjective norm interact significantly. They have direct positive effects on behavioral intention and then indirectly influence actual behavior through this intention. Actual sustainable behaviors of private sectors have significantly positive effects on the sustainable development of cities. We offer theoretical and managerial implications for public and private sectors on the basis of the findings to ensure and promote the sustainability performances of PTI projects.
\end{abstract}

Keywords: infrastructure; PPP; sustainable development; sustainable behaviors

\section{Introduction}

Public-private partnership (PPP), as an innovative procurement mode, has been playing a vital role in developing public infrastructures in China [1,2], for instance, social (e.g., prisons, social housing, and hospitals) and economic (e.g., highways, bridges, and high-speed rails) infrastructures [3-5]. The demand for public infrastructure is continuously increasing due to the acceleration of urbanization and the rapid growth of the economy [3,6]. In 2014, the State Council of China published the "Guidance for Strengthening the Management of Local Government Debts", which restricted local governments' financing platforms and funding [7]. Faced with the shortage of funds [8], governments were compelled to seek cooperation from private sectors, who can provide a large amount of funds, to participate in public infrastructure construction $[9,10]$. Under this economic circumstance, PPP has experienced a rapid expansion and a boom period for the last five years in China [5,11]. As of 30 September 2017, the number of Chinese PPP projects recorded has reached 14,220. The gross investment in these projects has amounted to 17.8 trillion yuan [12].

However, a series of social issues appear when an increasing number of PPPs are applied in infrastructure development because private sectors are attracted to profits [6]. For instance, private sectors may lower the quality of infrastructures and public services for reducing construction costs, ignore environmental protection and corporate social responsibility (CSR), and pay further attention 
to projects with high financial returns [13]. As a result of disputes on the expense of pollution emission with the local government, Huijin, a wastewater treatment company, discharged more than one million tons of wastewater to the Songhua River, causing severe effects in social and environmental aspects [14]. Some private and even public sectors do not integrate the three aspects of economics, environment, and society into their implementation process $[15,16]$. Hence, the concept of sustainability must be considered to understand the serious implication of PPP projects [17].

Sustainable development is a serious challenge worldwide and for our future generations [18]. The importance of infrastructures, procured by governments or PPPs, can be witnessed by all sectors of the society and international policies on "green" and "social" public projects [19]. The principles of sustainable development are often divided into the triple bottom line, namely, environmental, economic, and social frameworks, for the activities of regions, corporations, and individuals [20-22]. Scholars, such as Ugwu and Kumaraswamy, have established a sustainability appraisal system in infrastructure projects and investigated the improvements, barriers, and determinations for sustainable development [23]. However, their concerns were focused largely on macrolevel policy planning but minimally on microlevel construction behaviors [24]. Numerous scholars have studied relationship governance [25], risk management [26,27], and performance appraisal [28] with regard to private sectors. However, the research on private sectors' sustainable behaviors is limited, which motivated us to investigate whether and how behaviors influence the sustainability performance of infrastructures provided via PPP modality $[17,29]$ as one of the objectives of this study. Another objective is to propose corresponding strategies for improving the sustainability performance from the perspectives of governments and private sectors. To achieve the research goals, we use the modified theory of planned behavior (TPB), a questionnaire survey, and the structural equation modeling (SEM) method. We perform an empirical research on the influencing factors to investigate the sustainability influenced by private sectors' behaviors [30]. This paper can provide suggestions for local governments and relevant private sectors on how to improve the sustainability performance and facilitate the sustainable development of PPP-type infrastructure (PTI) projects [9]. Furthermore, this study can expand the research scope of the sustainability performance of PTI projects and provide the basis for future research on PPP and even sustainable development.

The paper is organized as follows. Section 2 lays out the literature review of sustainability and corresponding factors in PTI projects. Section 3 presents the theoretical model and research hypotheses. Section 4 elaborates the research methodology and questionnaire design. Data analysis, model test, and result discussion are given in Section 5. The final section concludes the research and provides some implications.

\section{Literature Review}

\subsection{Understanding Sustainability in PTI Projects}

As defined in the Brundtland Report "Our Common Future" in 1987 [31], the concept of "sustainable development" has been extensively supported and addressed by people from all walks of life and governments worldwide [32]. Evaluation not only on the macroscopic level (e.g., national strategy) but also on the microscopic level (e.g., project sustainability appraisal or feasibility study) $[8,13,33]$ in the perspective of sustainable development is crucial. On one hand, infrastructure projects have non-negligible effects on the economy, environment, and society, as three bottom lines in sustainability [34,35], due to a massive investment and a large consumption of resources [18]. These projects can promote economic growth and dramatically provide conducive effects on social welfare [36]. On the other hand, Shen et al. highlighted that infrastructure projects can also balance social disparity and improve regional competitiveness in developed and developing countries [9]. Numerous scholars argued that the benefits of infrastructure projects for society are remarkable [37,38], but their long-range sustainability performance is sometimes neglected [39]. 
The shortage of government fiscal funds and the constraint of managerial experience have resulted in the rapid development of PPP mode for establishing and operating infrastructure projects $[9,39]$. PPPs emerged when public sectors cooperated with private sectors to construct large-scale projects on the basis of mutual trust, which is different from hierarchical relationships [40]. The increasing number of PPP projects has attracted the attention of scholars in related fields [41]. The infrastructure applications of PPP mode has been investigated in several approaches, including relation governance [25], concessionaire determinants [42], contract governance [43], risk allocation [26,27], critical factors [44,45], and sustainability performance $[23,24,46]$. In this context, numerous scholars are concerned with the unsustainability of PTI projects, so they explore appropriate research angles and methods to ensure and improve sustainability performances [9].

Through a questionnaire survey with stakeholders in a PPP, scholars from India discovered that the sustainability of PTI projects nearly depends on the contribution of private sectors to sustainable development, such as efficient project implementation, resource utilisation efficiency, and so on [47]. Similarly, Hueskes et al. summarized that if the procuring government prefers projects with further sustainability performance, then they should encourage private corporations involved in the contract to perform further sustainable behaviors. They also argued that PPPs are sometimes regarded as vehicles for achieving sustainability goals [19]. According to Xiong, innovation (either in terms of technology or business model), as the most important power in facilitating sustainable development, is easily implemented by private sectors [14]. In addition, some studies emphasized the importance of CSR to sustainable construction [48,49]. CSR stresses ethical behavior with regard to the economy, society, and environment, which is similar to the three pillars of sustainability [46]. If corporations place sustainability as a company objective, then they will propose CSR policies to conduct necessary procedures [13]. However, despite its capability to bring benefits across all sustainability aspects, CSR has been rarely considered [46]. Although private sectors are closely linked to project sustainability, investigations from this perspective are limited. As a result, this study aims to bridge the research gap.

\subsection{Factors Related to Sustainable Behaviors in PTI Projects}

Numerous studies analyze the sustainability performances of projects [50,51]. Zhang et al. introduced a new model for evaluating the sustainability of infrastructure projects and then compared it between urban and rural areas by focusing on efficiency and equity perspectives [52]. Belgian scholars compared the difference between strong sustainability and weak sustainability through an analysis of 27 PTI projects to find an effective method for improving sustainability performance. Moreover, their research showed that social dimensions of sustainability are often neglected due to the shortage of measurable social indicators [19]. Greek scholars investigated the social and environmental sustainability of infrastructure projects in rural areas on the basis of a local PPP scheme. They found that the sustainability performance of infrastructure projects procured under a PPP is often better than that procured in the traditional way. This result indicated that under a PPP contract, if the government implements moderate specifications and regulations on private sectors, then enhanced sustainability performance with improved cost-effectiveness, innovative technology, and "green" incentives will be demonstrated [53]. Shen et al. collected 87 large-scale project feasibility reports to measure sustainability performance. They constructed an evaluation system, including 18 economic indicators, 8 environmental indicators, and 9 social indicators, which can be used as guidance for assessing whether the constructing behaviors of private sectors are sustainable [13]. The vast majority of firms in China have paid minimal attention to the deep exploration of sustainability performance or sustainable behaviors. Australian scholars investigated three leading construction firms and identified 29 aspects of sustainable behaviors, including green innovation, corporate governance, and water conservation [54]. Similarly, when assessing the sustainability of a wastewater treatment system, Annelies et al. separately listed the economic, environmental, and social indicators. They found that operation costs, land area, and heavy metals are crucial for sustainability performance [55]. Meanwhile, the stimulation of sustainable behavior, as a social indicator, also plays a non-negligible 
role in promoting sustainability [55]. More than 500 sustainability indicators have been listed by the Compendium of Sustainable Development Indicator Initiatives, including global (67), national (103), provincial (72), and local (289) indicators. These indicators are used to evaluate whether the goals of various policies, infrastructure projects, and construction contracts are in accordance with the goals of sustainable development [56]. Nilesh et al. also established a sustainability criteria system of infrastructure development focused on the Indian PPP market, which is the second largest market in the world, so that private sectors could consider these criteria in implementing further sustainable management measures [47].

Scholars have also analyzed factors that lower the sustainability performance of infrastructure projects [39]. Ezeah indicated that unbalanced relationship among local, state, and private sectors, low funding efficiency, weak legal framework, and polices without clear strategies for realization are the main limitations of sustainability performance [57]. By studying the sustainability of infrastructure projects from a project management perspective, numerous scholars have identified various constraints, for instance, poorly trained administrators and workers, complicated managerial rules [58], lack of awareness in sustainable development [59], and weak executive operation [17]. Chang et al. stated that the awareness of construction companies in China on sustainable development remains insufficient, and whether companies are performing sustainably is often ignored [54]. Through a questionnaire survey completed by on-site personnel, Zhou et al. identified the gaps between awareness and actual behaviors in the adoption of sustainable construction, and sustainable practices need to be popularized to a great extent, which reflects the necessity of our research [60].

On the basis of the discussions of existing literature, this study aimed to analyze private sectors' behaviors, which closely connect with sustainability performance.

\section{Theoretical Model and Research Hypotheses}

\subsection{Modified TPB}

The TPB proposed by Icek Ajzen in the 1980s states that people's behaviors are the results after deep considerations [61]. By selecting the expectancy-value theory as the starting point, the TPB explains individual behavior preference and decision-making course after processing the acquired information [62]. The TPB indicates that behavioral attitude, subjective norm, and perceived behavioral control conjointly determine individual behavioral intention [63]. These three decisive factors are based on a latent belief structure, under which behavioral beliefs have beneficial or adverse effects on behaviors. Similarly, normative belief results in social pressure and subjective norm, and control belief may control actual behaviors at execution [61].

Specifically, two variables, namely, perceived usefulness and usability, which are introduced in the technology acceptance model (TAM), must be considered in technical practice due to their potential complementation and theoretical compatibility for increasing the TPB's explanatory power [64]. For private sectors, perceived usefulness mainly refers to enhancing the corporation's reputation and promoting industrial changes accompanied by private sectors' sustainable behaviors. Perceived usability is an important factor before considering sustainable behaviors. On the basis of TAM, when individuals apply a new process or product, they often compare it with the existing process or product. Hence, private sectors may compare the usefulness and usability perceptions of sustainable behaviors with traditional behavior, considering the advantages and disadvantages of the two approaches [65].

By retaining original variables, this study added perceived usefulness and usability as causal latent variables to maintain the good explanatory capability of the model. Lin et al. claimed that infrastructure sustainability considerably influences urban sustainable development [66]. Therefore, the sustainable development of a city is used as an ultimate latent variable in this study for measuring the influence of private sectors' sustainable behaviors on the city. Figure 1 shows the modified TPB conceptual model. The dashed line represents the original hypothesis of the theoretical model, and the solid line indicates the model hypothesis of this study. 


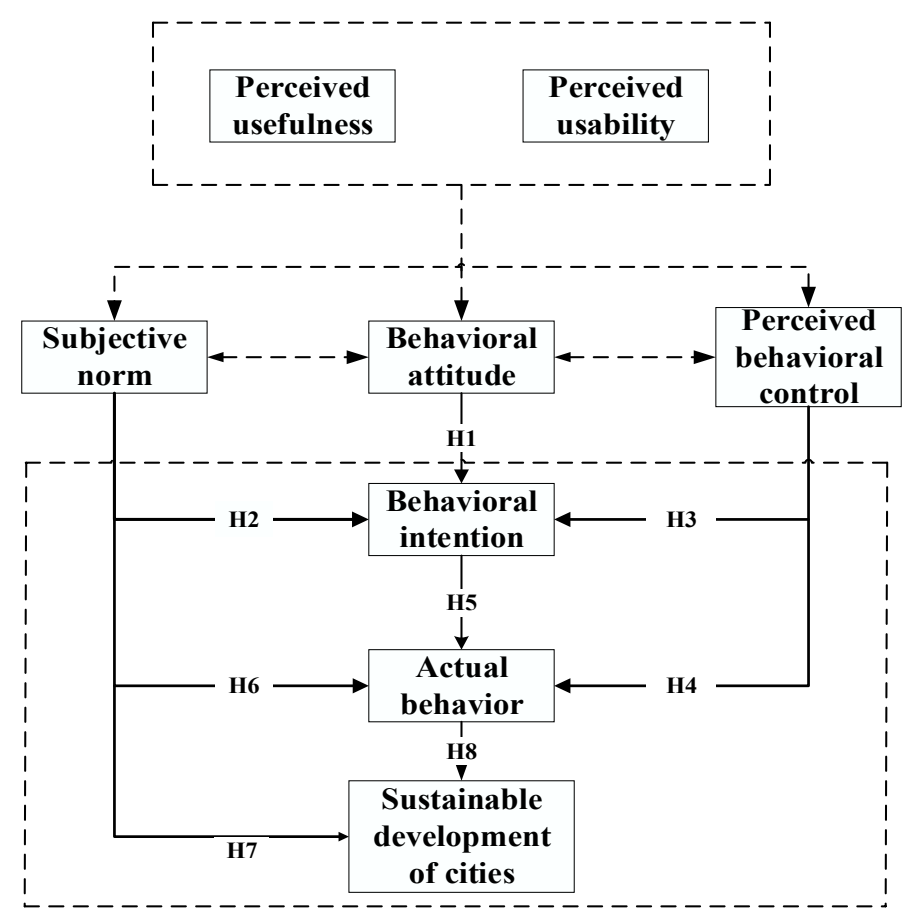

Figure 1. Conceptual model.

\subsection{Research Hypotheses}

\subsubsection{Relationships among Behavioral Attitude, Subjective Norm, and Behavioral Intention}

Behavioral attitude, as the important anterior variable of behavioral intention, can be defined as the overall evaluation on specific behavior [67]. This study regarded perceived usefulness and usability as extended elements in the TPB model which are used to assess the efficiency and convenience of sustainable behaviors, respectively. Behavioral intention is noted as the precondition and immediate determinant of actual behavior. Scholars have suggested that behavioral attitude positively affects behavioral intention. For instance, through a questionnaire survey completed by 3029 respondents on consumers' willingness to select electric vehicles, Hidrue et al. found that the more positive the behavioral attitude consumers have, the stronger the behavioral intention they will have [67].

Subjective norm refers to the perceived pressure from the society or groups who expect a subject to perform in a certain way [68]. In the context of this study, pressure includes the governments' strategies, evaluations from all sectors of society, and influences from other companies' behaviors. Kan et al. stated that a positive subjective norm will considerably promote behavioral intention [69]. In comparison with traditional ways, the subjective norm of sustainable behaviors is strong. For instance, if other companies decide to perform green behaviors, then following this decision is wise, considering corporate image and reputation, despite the high cost in the initial application stage.

Two hypotheses are proposed on the basis of previous considerations:

Hypothesis 1 (H1). Behavioral attitude has significant positive effects on behavioral intention.

Hypothesis 2 (H2). Subjective norm has significant positive effects on behavioral intention.

3.2.2. Relationships among Perceived Behavioral Control, Behavioral Intention, and Actual Behavior

Perceived behavioral control, which reflects individuals' previous experience and expected impediment, is defined as the degree of ease or difficulty perceived by individuals who want to perform specific behaviors [68]. In this context, perceived behavioral control includes perceptions of cost, time limit, quality, and safety. 
When individuals think that they have additional resources or opportunities and less expected impediment, their perceived behavioral control will be fierce. Consistent with Axsen and Kurani's research conclusion, the more the ability individuals have to use resources and solve perceived problems, the more likely the intention and even the actual behaviors will be generated. As new behaviors may require new workers, relation governance is regarded as an observational variable of perceived behavioral control.

In the TPB model, behavioral intention is the immediate determinant of actual behavior. In accordance with the theory of organizational behavior, perceived behavioral control and behavioral intention conjointly determine the individual behavior of private sectors. Through a survey of Canadian office workers for reducing commuter car use, Abrahamse et al. found that perceived behavioral control moderated the relation and behavioral intention acted as the mediation between intention and actual behavior [70].

Three hypotheses are proposed on the basis of the previous considerations:

Hypothesis 3 (H3). Perceived behavioral control has significant positive effects on behavioral intention.

Hypothesis 4 (H4). Perceived behavioral control has significant positive effects on actual behavior.

Hypothesis 5 (H5). Behavioral intention has significant positive effects on actual behavior.

3.2.3. Relationships among the Subjective Norm, Actual Behavior, and Sustainable Development of a City

Intragenerational and intergenerational equities, the two key principles of sustainable development, emphasize that development should meet the needs of the present generation without compromising the capability of future generations to meet their own needs [47]. If the sense of sustainable development is deeply rooted in people from all walks of life, including construction of infrastructure projects, then sustainable development goals will be further implemented. Therefore, this study measured sustainability brought by the influence of sustainable behaviors, for instance, reducing air and water pollution, relieving noise pollution, reducing resource and energy consumption, and effecting other low-carbon behaviors.

Additional studies indicate that external pressure must be considered when promoting a new technology or behavior. In our work, subjective norm refers to the external environment and also the social influence to some extent. Greek scholars investigated 29 cases to examine how social innovation evolves and found that although actual behaviors drive social innovation, subjective norm brought by Greek government departments and the society is the main cause [71]. Subjective norm, often seen as a social pressure, will play a non-negligible role in promoting sustainable behavior and then will considerably affect the sustainable development of a city due to the minimal motivation to change and the profit-making mindset of private sectors [72].

Three hypotheses are proposed on the basis of the previous considerations:

Hypothesis 6 (H6). Subjective norm has significant positive effects on actual behaviors.

Hypothesis 7 (H7). Subjective norm has significant positive effects on the sustainable development of a city.

Hypothesis 8 (H8). Actual behavior has significant positive effects on the sustainable development of a city.

\section{Research Methodology}

\subsection{Structure Equation Model}

As SEM is widely used in numerous research areas, including social science, economics, marketing, management, and behavioral science, it has been proven to be efficient for analyzing and testing the causal relationship between observed and latent variables since the 1980s [73,74]. This method plays 
an excellent role in identifying key indicators and factors [39]. For example, Jiao et al. adopted SEM to identify the critical factors for sustainable urbanization in a case study of China [30]. Shen et al. applied SEM to analyze the most important factor that influences the passenger satisfaction with urban railway transit in Suzhou, China [75]. To compensate for the deficiency of traditional statistical approaches that cannot analyze latent variables, SEM has been one of the most important methods in the field of multivariate data analysis [76]. Therefore, we used SEM to understand the complex relationships between unobservable variables and the identified influencing factors. The AMOS 21.0 software was adopted for applying SEM during the research process.

\subsection{Questionnaire}

A questionnaire survey was conducted to collect respondents' first-hand information. Our survey consists of seven latent variables, namely, perceived usefulness, perceived usability, subjective norm, perceived behavioral control, behavioral intention, actual behavior, and sustainable development of a city. The five-point Likert scale was used to measure respondents' viewpoints, in which 1 represents negligible and 5 represents very important. This scale has been proven to be an efficient method for rating the importance among the factors by collecting respondents' opinions [77]. Considering that the survey items should be easy to understand, we requested 10 experts from the field of public management to test the readability of the questionnaire. We modified a few survey items and adjusted some descriptions on the basis of the advice provided by experts. Table 1 shows the final questionnaire of this study and Table 2 lists the characterization of the survey sample.

The number of distributed questionnaires was 280. The criteria for selecting the sample respondents were as follows: (1) they have hands-on experience in companies that participate in ongoing or recently completed PPP projects; (2) they come from multiple departments, such as design and site construction; and (3) they are willing to participate in the survey. By eliminating 22 questionnaires that were not completed or perfunctory, we obtained a total of 258 valid questionnaires. The rate of valid questionnaires was $92.1 \%$, which meets the statistical requirements of SEM.

Table 1. Survey items of private sectors' behaviors and corresponding indices.

\begin{tabular}{|c|c|c|c|c|}
\hline Variables and Survey Items & $\begin{array}{l}\text { Factor } \\
\text { Loading }\end{array}$ & $\begin{array}{c}\text { Cronbach's } \\
\text { Alpha }\end{array}$ & AVE & Literature \\
\hline \multicolumn{5}{|l|}{ Perceived usefulness (PU1): } \\
\hline 1. It is suitable for me to take sustainable behaviors. & 0.860 & & & \\
\hline 2. Sustainable behaviors can increase construction efficiency. & 0.852 & 0.791 & 0.655 & {$[78,79]$} \\
\hline 3. Sustainable behaviors have positive effects on corporate image. & 0.810 & & & \\
\hline \multicolumn{5}{|l|}{ Perceived usability (PU2): } \\
\hline 1. Companies can learn how to take sustainable behaviors quickly. & 0.736 & & & \\
\hline 2. Taking sustainable behaviors are easier than traditional ways. & 0.766 & 0.810 & 0.591 & [80] \\
\hline 3. The processes of sustainable behaviors are convenient to operate & 0.671 & & & \\
\hline \multicolumn{5}{|l|}{ Subjective norm (SN): } \\
\hline 1. Other companies in the same field are taking sustainable behaviors. & 0.830 & & & \\
\hline 2. Sustainable behaviors get great social evaluation. & 0.817 & 0.847 & 0.667 & {$[63,81]$} \\
\hline 3. Sustainable behaviors are supported by governments strongly. & 0.653 & & & \\
\hline \multicolumn{5}{|l|}{ Perceived behavioral control (PBC): } \\
\hline 1. I will consider cost increase accompanied by sustainable behaviors. & 0.778 & & & \\
\hline 2. I will consider possible construction delay accompanied by them. & 0.833 & 0.905 & 0.672 & {$[82,83]$} \\
\hline 3. I need govern new relations if I employ better trained workers and managers. & 0.784 & & & \\
\hline 4. I will take construction quality and safety into consideration. & 0.723 & & & \\
\hline \multicolumn{5}{|l|}{ Behavioral intention (BI): } \\
\hline 1. I will take traditional behaviors unchangeably. & 0.655 & & & \\
\hline 2. I will take sustainable behaviors step by step. & 0.681 & 0.750 & 0.504 & {$[63,84]$} \\
\hline 3. I will take sustainable behaviors more frequently in later time. & 0.665 & & & \\
\hline \multicolumn{5}{|l|}{ Actual behavior (AB): } \\
\hline 1. I just start taking sustainable behaviors in some aspects. & 0.743 & & & \\
\hline 2. I take sustainable behaviors in all aspects skillfully. & 0.875 & 0.888 & 0.739 & {$[84,85]$} \\
\hline 3. I advise other companies to take sustainable behaviors too. & 0.835 & & & \\
\hline \multicolumn{5}{|l|}{ Sustainable development of cities (SD): } \\
\hline 1. Sustainable behaviors can reduce air, water, and noise pollution. & 0.844 & & & \\
\hline 2. Sustainable behaviors can reduce resource consumption in city. & 0.880 & 0.891 & 0.632 & {$[19,86]$} \\
\hline 3. Sustainable behaviors can reduce energy consumption in city. & 0.797 & & & \\
\hline 4. Private sector's behaviors can facilitate other low-carbon behaviors. & 0.671 & & & \\
\hline
\end{tabular}


Table 2. Characterization of survey sample.

\begin{tabular}{cccc}
\hline Characterization & Type & Frequency & Percentage (\%) \\
\hline Gender & Male & 182 & 70.54 \\
& Female & 76 & 29.46 \\
\hline Age & $18-30$ years old & 54 & 20.93 \\
& $30-45$ years old & 141 & 54.65 \\
& $\geq 45$ years old & 63 & 24.42 \\
\hline Educational background & Senior high school or below & 37 & 14.34 \\
& Associate degree or bachelor's degree & 169 & 65.50 \\
& Master's degree or PhD & 52 & 20.16 \\
\hline Monthly income & Less than 5000 yuan & 34 & 13.18 \\
& $5000-10,000$ yuan & 146 & 56.59 \\
& More than 10,000 yuan & 78 & 30.23 \\
\hline Position & Administrative staff & 64 & 24.81 \\
& Basic staff & 194 & 75.19 \\
\hline Related work years & $\leq 5$ years & 32 & 12.40 \\
& $5-10$ years & 161 & 62.40 \\
& $\geq 10$ years & 65 & 25.20 \\
\hline
\end{tabular}

\section{Results and Discussions}

\subsection{Reliability and Validity Analysis}

Reliability is regarded as the degree of consistency of the consequences of different test measurements. At present, scholars often use Cronbach's alpha coefficient $(\alpha)$ to test reliability. The closer the $\alpha$ is to 1 , the more consistent the questionnaire items are with the corresponding variables, which indicates that questionnaire items are well designed. Generally, Cronbach's alpha coefficient is required to be more than 0.7. If $\alpha$ is more than 0.8 , then the analysis is deemed to have a high degree of reliability [86]. SPSS20.0 was utilized to test the reliability of our study. The $\alpha$ of the questionnaire is 0.916 and the $\alpha$ of the seven latent variables ranges from 0.75 to 0.905 . Therefore, the reliability of our questionnaire is great, regardless of holistic or part aspects.

Validity analysis contains convergent, discriminant, and content validities. Average variance extracted (AVE) values are used to test convergent and discriminant validity [87], and factor loadings after orthogonal rotation are utilized to test content validity. The AMOS20.0 software was adopted to calculate the AVE values. The AVE values of the seven latent variables are more than 0.5 (Table 1), so the convergent validity of our questionnaire is great. Table 3 shows that the square root of the AVE exceeds the correlation between the two different constructs for all construct pairs, which suggests that the discriminant validity is adequate. The factor loadings after the orthogonal rotation of indicators range from 0.653 to 0.880 (Table 1), so the content validity of our questionnaire is great.

Table 3. AVE and correlation matrix.

\begin{tabular}{lcccccccc}
\hline & AVE & $\mathbf{1}$ & $\mathbf{2}$ & $\mathbf{3}$ & $\mathbf{4}$ & $\mathbf{5}$ & $\mathbf{6}$ & $\mathbf{7}$ \\
\hline 1. PU1 & 0.655 & 0.81 & - & - & - & - & - & - \\
2. PU2 & 0.591 & 0.39 & 0.77 & - & - & - & - & - \\
3. SN & 0.667 & 0.47 & 0.46 & 0.82 & - & - & - & - \\
4. PBC & 0.672 & 0.27 & 0.38 & 0.43 & 0.82 & - & - & - \\
5. BI & 0.504 & 0.18 & 0.29 & 0.37 & 0.46 & 0.71 & - & - \\
6. AB & 0.739 & 0.39 & 0.43 & 0.41 & 0.43 & 0.51 & 0.86 & - \\
7. SD & 0.632 & 0.56 & 0.41 & 0.18 & 0.27 & 0.44 & 0.57 & 0.79 \\
\hline
\end{tabular}

\subsection{Model Test}

The AMOS20.0 was used to fit the model, and then we found that several main goodness-of-fit (GOF) measures did not meet the recommended levels which have been suggested in previous 
studies [88,89]. Thus, the initial SEM model needed to be refined and optimized. On the basis of various reports on SEM models, O'Rourke et al. stated that most models cannot meet all fit standards the first time due to deviations of collected data or deficiencies of the model itself [90]. We refined the model on the basis of the suggestions of GOF measures and the hypotheses proposed by TPB until the model presented a good fit and the GOF measures met the recommended levels. Table 4 shows the comparison of the GOF measures between initial and refined models. Figure 2 presents the action path of the private sectors' intention.

Table 4. Compatibility test before and after model modification.

\begin{tabular}{cccccc}
\hline GOF Measures & Recommended Levels & Before Refining & Evaluation & After Refining & Evaluation \\
\hline$\chi^{2} / \mathrm{df}$ & $<3$ & 2.258 & Acceptable & 1.964 & Acceptable \\
RMR & $<0.05$ & 0.104 & Unacceptable & 0.048 & Acceptable \\
RMSEA & $<0.08$ & 0.065 & Acceptable & 0.057 & Acceptable \\
GFI & $>0.9$ & 0.879 & Unacceptable & 0.901 & Acceptable \\
AGFI & $>0.9$ & 0.846 & Unacceptable & 0.912 & Acceptable \\
RFI & $>0.9$ & 0.864 & Unacceptable & 0.927 & Acceptable \\
TLI & $>0.9$ & 0.920 & Acceptable & 0.938 & Acceptable \\
NFI & $>0.9$ & 0.884 & Unacceptable & 0.900 & Acceptable \\
PGFI & $>0.5$ & 0.691 & Acceptable & 0.700 & Acceptable \\
PNFI & $>0.5$ & 0.758 & Acceptable & 0.765 & Acceptable \\
\hline
\end{tabular}

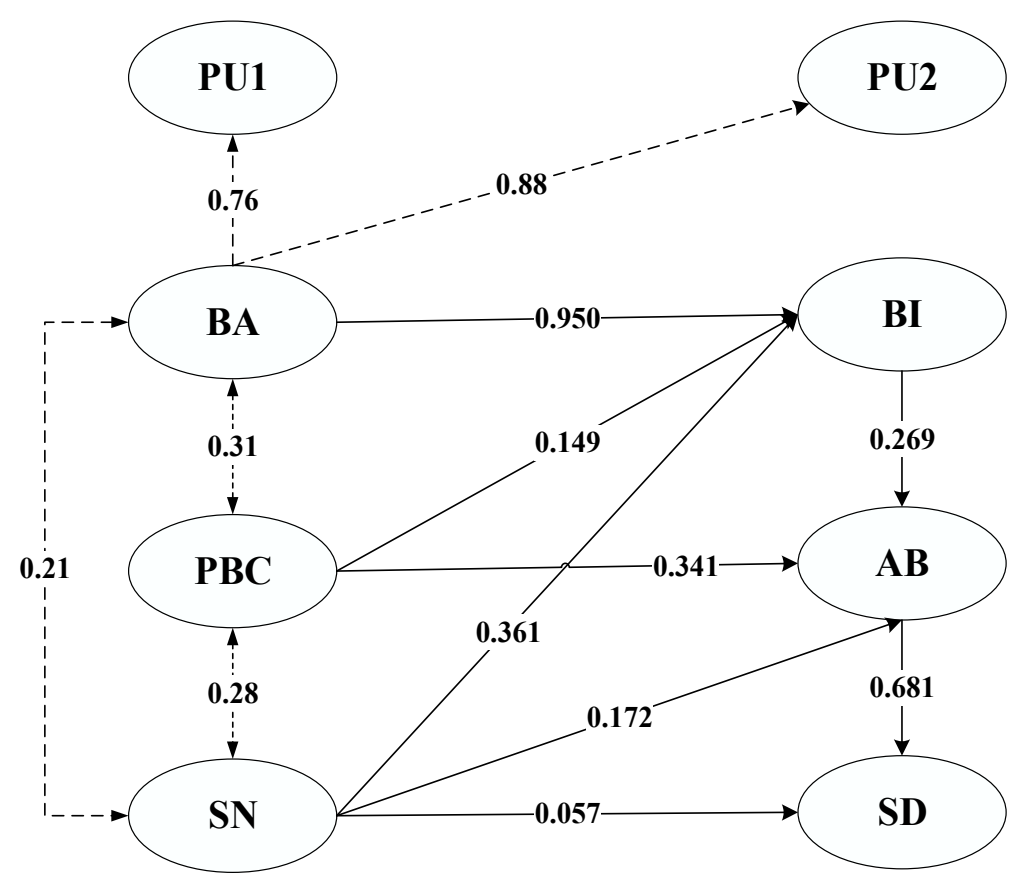

Figure 2. Action path.

At present, the academic circles often use composite reliability (CR) to test the degree of internal consistency of observable variables, in which CR meets the recommended level when its value is more than 0.7 [91]. The CR values can be obtained from the following equation:

$$
\rho_{c}=\frac{\left(\sum \lambda\right)^{2}}{\left(\sum \lambda\right)^{2}+\sum \theta}
$$

In this equation, $\rho_{\mathrm{c}}$ denotes the $\mathrm{CR}$ value; $\lambda$ represents the standardized coefficient of observational variables, namely, factor loading; and $\theta$ indicates the error variance of variables. After calculation, the $C R$ values range from 0.74 to 0.91 , which exceed 0.7 . Thus, the model has great internal quality. 


\subsection{Hypothesis Verification}

Table 5 lists the path coefficients and consequences of hypothesis verification accompanied with refined SEM. We utilized a nonstandardized path coefficient for the analysis, which is meaningful in statistics. We need to verify the hypotheses on the basis of the empirical results.

Table 5. Path coefficients and test results.

\begin{tabular}{|c|c|c|c|c|}
\hline Hypothesis Path & Path Coefficients & $\mathrm{T}$ & $p$ & Test Results \\
\hline $\mathrm{BI} \leftarrow \mathrm{BA}$ & 0.950 & 5.129 & $* * *$ & Supported \\
\hline $\mathrm{BI} \leftarrow \mathrm{SN}$ & 0.361 & 3.561 & $* * *$ & Supported \\
\hline $\mathrm{BI} \leftarrow \mathrm{PBC}$ & 0.149 & 2.12 & * & Supported \\
\hline $\mathrm{AB} \leftarrow \mathrm{PBC}$ & 0.341 & 5.58 & $* * *$ & Supported \\
\hline $\mathrm{AB} \leftarrow \mathrm{BI}$ & 0.269 & 3.476 & $* * *$ & Supported \\
\hline $\mathrm{AB} \leftarrow \mathrm{SN}$ & 0.172 & 2.926 & $* *$ & Supported \\
\hline $\mathrm{SD} \leftarrow \mathrm{SN}$ & 0.057 & 0.800 & 0.424 & Unsupported \\
\hline $\mathrm{SD} \leftarrow \mathrm{AB}$ & 0.681 & 6.423 & $* * *$ & Supported \\
\hline
\end{tabular}

On the basis of Table 5, behavioral attitude has significant positive effects on behavioral intention ( $\beta=0.95$, T value is $5.129, p<0.001$ ), so $\mathrm{H} 1$ is verified. Subjective norm has significant positive effects on behavioral intention ( $\beta=0.361$, T value is $3.561, p<0.001$ ), so $\mathrm{H} 2$ is verified. Perceived behavioral control has significant positive effects on behavioral intention $(\beta=0.149$, T value is $2.12, p=0.034)$, so H3 is verified. Perceived behavioral control has significant positive effects on actual behavior ( $\beta=0.341$, T value is $5.58, p<0.001)$, so $\mathrm{H} 4$ is verified. Behavioral intention has significant positive effects on actual behavior ( $\beta=0.269$, T value is $3.476, p<0.001)$, so H5 is verified. Subjective norm has significant positive effects on actual behaviors ( $\beta=0.172$, T value is $2.926, p<0.001$ ), so H6 is verified. Subjective norm does not have significant positive effects on the sustainable development of a city ( $\beta=0.057$, T value is $0.800, p=0.424$ ), so $\mathrm{H7}$ is not verified. Actual behavior has significant positive effects on the sustainable development of a city ( $\beta=0.681$, T value is $6.423, p<0.001)$, so $\mathrm{H} 8$ is verified. Except for H7, hypotheses are all verified.

\subsection{Discussions}

The SEM analysis indicates that perceived usefulness and usability conjunctively explain the variable-behavioral attitude, whose path coefficients are respectively 0.76 and 0.88 , reflecting that they are the main influencing factors of actual behavior. Similar to the research conclusion of Fan et al., good perceptions of usefulness and usability are preconditions of strong behavioral attitude [65]. Behavioral attitude, perceived behavioral control, and subjective norm interact significantly. They have direct positive effects on behavioral intention and influence actual behaviors indirectly via behavioral intention.

Behavioral attitude $\rightarrow$ behavioral intention (0.95), with the most significant effect, reflects that behavioral attitude is the major factor influencing behavioral intention. Similar to the research conclusion of Gloukhovtsev, behavioral attitude considerably influences intention in ethical consumer behavior; moreover, perceived behavioral control, subjective norm, and moral intensity help bridge the attitude-intention and attitude-behavior gaps [92]. On the contrary, behavioral intention $\rightarrow$ actual behavior (0.269), with insignificant effect, indicates that despite a strong intention, actual behaviors are rarely found. Behavioral intention is restrained by subjective norm and perceived behavioral control under ideal conditions, so private sectors' behavioral intention is greater than the actual behavior at the present stage.

Moreover, perceived behavioral control and subjective norm have direct effects on actual behaviors, the values of which are 0.341 and 0.172 , respectively. Perceived behavioral control influences actual behaviors in a more significant way than subjective norms. In our study, perceived behavioral control directly influences private sectors because they are attracted to profits. This situation 
remains until subjective norms are enforced by policies. When studying organic consumerism behaviors through TPB, Johe also emphasized the importance of perceived behavioral control on actual behaviors [93].

The path coefficient of the actual behavior $\rightarrow$ sustainable development of a city is 0.681 , also with a considerable effect, suggesting the public knows the importance of promoting sustainable behaviors to facilitate the sustainable development of a city. However, the main contradiction is that intention is not transformed to actual behavior in a high degree. Therefore, an urgent problem to be solved is how to increase the transformation rate of intention $\rightarrow$ actual behavior steadily. Increasing the transformation rate by enforcing policies and regulations is simple but effective for governments. From a long-term perspective, the most appropriate approach is improving the CSR and awareness of sustainable development.

The path coefficient of the subjective norm $\rightarrow$ sustainable development of a city is only 0.057 , but the subjective norm has significant effects on behavioral intention and actual behavior. This result indicates that the pressure of policies could facilitate the promotion of sustainable behaviors of private sectors, and to some extent, it will help generate other low-carbon behaviors in the city.

\section{Conclusions and Implications}

Research on the sustainable behaviors of private sectors is important for assisting the government in adopting strategies and policies to propel sustainable development, which also has a theoretical and practical significance in constructing PTI projects. An innovation in this research is to conduct an empirical analysis on the gaps between sustainable behavioral intention and actual behavior from the perspective of private sectors via modified TPB and questionnaire survey. To some extent, this work aims to compensate for the research deficiency in this field. This study shows the current situations and behavioral rules of private sectors' sustainable behaviors and presents strongly operational methods for governments and companies. These findings provide a useful reference for upper-level decision makers and governments to implement appropriate measures for improving infrastructure sustainability.

To facilitate the sustainable development of a city and enterprise transformation, we present management suggestions from the perspectives of the government and enterprises on the basis of the research findings and advice of the respondents:

(1) Perspective of the government: On one hand, introducing relevant laws and regulations is impending for governments to guide construction enterprises in performing as many as possible sustainable behaviors. Then, the transformation rate of intention $\rightarrow$ actual behavior is increased by the coerciveness of laws and regulations. On the other hand, under PPP mode, the government and private sectors establish a project company together. Although private sectors always operate the project company, public sectors can enforce necessary specifications and supervisions on private sectors to facilitate further sustainability performance. Governments can also provide reward incentives to corporations and present preferential policies to stimulate further sustainable behaviors; otherwise, corporations should be penalized. In addition, governments should emphasize the importance of sustainable behaviors to increase the subjective norm of private sectors.

(2) Perspective of the private sectors: Companies are required to undertake CSR, which refers to numerous aspects, such as pollution, safety, and environmental protection. Private sectors must bridge the gaps between intention and actual behavior on sustainable construction. For example, at the bidding stage, companies should implement relevant policies about the limits of investments for ensuring economic sustainability. At the construction stage, companies should adopt sustainable materials and concentrate further on saving energy and water and protecting the environment for ensuring environmental sustainability. At the operating stage, private sectors should maintain the infrastructure for improving social sustainability. These suggestions can increase the perceived behavioral control and behavioral intention of private sectors, and then further sustainable behaviors will be performed.

The primary limitation of this study is that the data are all collected in the Chinese context. Considering the differences in different social environments, whether the research conclusions are 
suitable for other countries or regions remains to be verified. Thus, some PPP cases in other countries or regions should be brought to follow-up studies.

Author Contributions: S.Z. and K.X. conceived the study, analyzed the data, and completed the paper. Q.H. and S.F. collected the data. L.Z. revised it critically for important content.

Funding: This research received no external funding.

Acknowledgments: The authors would like to thank the experts who reviewed the manuscript.

Conflicts of Interest: The authors declare no conflicts of interest.

\section{References}

1. Mukhopadhyay, C. A nested framework for transparency in Public Private Partnerships: Case studies in highway development projects in India. Prog. Plan. 2016, 107, 1-36. [CrossRef]

2. Patil, N.A.; Tharun, D.; Laishram, B. Infrastructure development through PPPs in India: Criteria for sustainability assessment. J. Environ. Plan. Manag. 2016, 59, 708-729. [CrossRef]

3. Ke, Y. Is public private partnership a panacea for infrastructure development? The case of Beijing National Stadium. Int. J. Constr. Manag. 2014, 14, 90-100. [CrossRef]

4. Grimsey, D.; Lewis, M.K. Public Private Partnerships: The Worldwide Revolution in Infrastructure Provision and Projcet Finance; E. Elgar: Cheltenham, UK, 2005.

5. Wang, H.M.; Xiong, W.; Wu, G.D.; Zhu, D.J. Public-private partnership in Public Administration discipline: A literature review. Public Manag. Rev. 2018, 20, 293-316. [CrossRef]

6. Koppenjan, J.F.M.; Enserink, B. Public-Private Partnerships in Urban Infrastructures: Reconciling Private Sector Participation and Sustainability. Public Adm. Rev. 2009, 69, 284-296. [CrossRef]

7. State Council of China. Guidance for Strengthening the Management of Local Government Debts. Available online: http:/ /www.gov.cn/_zhengce/content/2014-10/02/content_9111.htm (accessed on 2 October 2014). (In Chinese)

8. Anwar, B.; Xiao, Z.; Akter, S.; Rehman, R.U. Sustainable Urbanization and Development Goals Strategy through Public-Private Partnerships in a South-Asian Metropolis. Sustainability 2017, 9, 1940. [CrossRef]

9. Shen, L.; Tam, V.; Gan, L.; Ye, K.; Zhao, Z. Improving Sustainability Performance for Public-PrivatePartnership (PPP) Projects. Sustainability 2016, 8, 289. [CrossRef]

10. Zhang, S.; Gao, Y.; Feng, Z.; Sun, W. PPP application in infrastructure development in China: Institutional analysis and implications. Int. J. Proj. Manag. 2015, 33, 497-509. [CrossRef]

11. Shi, J.G.; Si, H.Y.; Wu, G.D.; Su, Y.Y.; Lan, J. Critical Factors to Achieve Dockless Bike-Sharing Sustainability in China: A Stakeholder-Oriented Network Perspective. Sustainability 2018, 10, 2090. [CrossRef]

12. China Industrial Information. Transaction Amount of PPP Projects in China in 2017. Available online: http:/ / www.chyxx.com/industry/201803/617299.html (accessed on 9 March 2018). (In Chinese)

13. Shen, L.Y.; Tam, V.W.Y.; Tam, L.; Ji, Y.B. Project feasibility study: The key to successful implementation of sustainable and socially responsible construction management practice. J. Clean. Prod. 2010, 18, 254-259. [CrossRef]

14. Xiong, W.; Zhu, D. The theory and practice of PPP mode oriented by sustainable development. J. Tongji Univ. 2017, 28, 78-84.

15. Marcelino-Sádaba, S.; González-Jaen, L.F.; Pérez-Ezcurdia, A. Using project management as a way to sustainability. From a comprehensive review to a framework definition. J. Clean. Prod. 2015, 99, 1-16. [CrossRef]

16. Schipper, R.P.J.; Silvius, A.J.G. Sustainability in project management: A literature review and impact analysis. Syst. Bot. 2014, 4, 63-96.

17. Shen, L.; Asce, M.; Wu, Y.; Zhang, X. Key Assessment Indicators for the Sustainability of Infrastructure Projects. J. Constr. Eng. Manag. 2011, 137, 441-451. [CrossRef]

18. Wu, G.; Duan, K.; Zuo, J.; Zhao, X.; Tang, D. Integrated sustainability assessment of public rental housing community based on a hybrid method of AHP-entropyweight and cloud model. Sustainability 2017, 9, 603.

19. Hueskes, M.; Verhoest, K.; Block, T. Governing public-private partnerships for sustainability: An analysis of procurement and governance practices of PPP infrastructure projects. Int. J. Proj. Manag. 2017, 35, 1184-1195. [CrossRef] 
20. Edler, J.; Uyarra, E. Public Procurement of Innovation; Edward Elgar: Cheltenham, UK, 2012; pp. $224-237$.

21. Elkington, J. Cannibals with forks: The triple bottom line of 21st century business. Environ. Qual. Manag. 2010, 8, 37-51. [CrossRef]

22. Institution, B.S. Sustainability in Building Construction-General Principles; British Standards Institution: London, UK, 2007.

23. Ugwu, O.O.; Kumaraswamy, M.M.; Wong, A.; Ng, S.T. Sustainability appraisal in infrastructure projects (SUSAIP): Part 2: A case study in bridge design. Autom. Constr. 2006, 15, 229-238. [CrossRef]

24. Ugwu, O.; Kumaraswamy, M.; Wong, A.; Ng, S. Sustainability appraisal in infrastructure projects (SUSAIP): Part 1. Development of indicators and computational methods. Autom. Constr. 2006, 15, 239-251. [CrossRef]

25. Zou, W.; Kumaraswamy, M.; Chung, J.; Wong, J. Identifying the critical success factors for relationship management in PPP projects. Int. J. Proj. Manag. 2014, 32, 265-274. [CrossRef]

26. Bing, L.; Akintoye, A.; Edwards, P.J.; Hardcastle, C. The allocation of risk in PPP/PFI construction projects in the UK. Int. J. Proj. Manag. 2005, 23, 25-35. [CrossRef]

27. Jin, X.H. Neurofuzzy Decision Support System for Efficient Risk Allocation in Public-Private Partnership Infrastructure Projects. J. Comput. Civ. Eng. 2014, 24, 525-538. [CrossRef]

28. Tieva, A.; Junnonen, J.M. Proactive contracting in finnish ppp projects. Int. J. Strat. Prop. Manag. 2009, 13, 219-228. [CrossRef]

29. Engel, E.; Fischer, R.; Galetovic, A. The economic or infrastructure finance: Public-Private Partnership versus public provision. Eib Pap. 2010, 15, 40-69.

30. Jiao, L.; Shen, L.; Shuai, C.; He, B. A Novel Approach for Assessing the Performance of Sustainable Urbanization Based on Structural Equation Modeling: A China Case Study. Sustainability 2016, 8, 910. [CrossRef]

31. Brundtland, G.H. Report of the World Commission on Environment and Development. Environ. Policy Law 1987, 14, 26-30.

32. Satolo, E.G.; Simon, A.T. Critical analysis of assessment methodologies for intraorganizational sustainability. Manag. Environ. Qual. 2015, 26, 214-232. [CrossRef]

33. Therese, B. Does Collaboration Lead to Sustainability? A Study of Public-Private Partnerships in the Swedish Mountains. Sustainability 2017, 9, 1685.

34. Jenkins, B.; Annandale, D.; Morrison-Saunders, A. The evolution of a sustainability assessment strategy for Western Australia. J. Am. Dent. Assoc. 2003, 134, 97-101.

35. Sheate, W.R.; Dagg, S.; Richardson, J.; Aschemann, R.; Palerm, J.; Steen, U. Integrating the environment into strategic decision-making: Conceptualizing policy SEA. Environ. Policy Gov. 2003, 13, 1-18. [CrossRef]

36. Fay, M.; Toman, M.; Benitez, D.; Csordas, S. Infrastructure and Sustainable Development. Bone Marrow Transplant. 2010, 21, 1071-1073.

37. Djukic, M.; Jovanoski, I.; Ivanovic, O.M.; Lazic, M.; Bodroza, D. Cost-benefit analysis of an infrastructure project and a cost-reflective tariff: A case study for investment in wastewater treatment plant in Serbia. Renew. Sustain. Energy Rev. 2016, 59, 1419-1425. [CrossRef]

38. Gil, N.A.; Biesek, G.; Freeman, J. Interorganizational Development of Flexible Capital Designs: The Case of Future-Proofing Infrastructure. IEEE Trans. Eng. Manag. 2016, 62, 335-350. [CrossRef]

39. She, Y.; Shen, L.; Jiao, L.; Zuo, J.; Tam, V.W.Y.; Yan, H. Constraints to achieve infrastructure sustainability for mountainous townships in China. Habitat Int. 2018, 73, 65-78. [CrossRef]

40. Naoum, S. An overview into the concept of partnering. Int. J. Proj. Manag. 2003, 21, 71-76. [CrossRef]

41. Mazher, K.M.; Chan, A.P.C.; Zahoor, H.; Khan, M.I.; Ameyaw, E.E. Fuzzy Integral-Based Risk-Assessment Approach for Public-Private Partnership Infrastructure Projects. J. Constr. Eng. Manag. 2018, 144, 15. [CrossRef]

42. Shen, L.Y.; Wu, Y.Z. Risk Concession Model for Build/Operate/Transfer Contract Projects. J. Constr. Eng. Manag. 2005, 131, 211-220. [CrossRef]

43. Klijn, E.H.; Koppenjan, J. The impact of contract characteristics on the performance of public-private partnerships (PPPs). Public Money Manag. 2016, 36, 455-462. [CrossRef]

44. Babatunde, S.O.; Opawole, A.; Akinsiku, O.E. Critical success factors in public-private partnership (PPP) on infrastructure delivery in Nigeria. J. Facil. Manag. 2012, 10, 212-225. [CrossRef]

45. Ismail, S. Critical success factors of public private partnership (PPP) implementation in Malaysia. Asia-Pac. J. Bus. Adm. 2013, 5, 6-19. [CrossRef] 
46. Hutchins, M.J.; Sutherland, J.W. An exploration of measures of social sustainability and their application to supply chain decisions. J. Clean. Prod. 2008, 16, 1688-1698. [CrossRef]

47. Yu, Y.; Darko, A.; Chan, A.P.C.; Chen, C.; Bao, F.Y. Evaluation and Ranking of Risk Factors in Transnational Public-Private Partnerships Projects: Case Study Based on the Intuitionistic Fuzzy Analytic Hierarchy Process. J. Infrastruct. Syst. 2018, 24, 13. [CrossRef]

48. Hueting, R. Why environmental sustainability can most probably not be attained with growing production. J. Clean. Prod. 2010, 18, 525-530. [CrossRef]

49. Tam, V.W.Y.; Shen, L.Y.; Yau, R.M.Y.; Tam, C.M. On using a communication-mapping model for environmental management (CMEM) to improve environmental performance in project development processes. Build. Environ. 2007, 42, 3093-3107. [CrossRef]

50. Shen, L.Y.; Wu, M.; Wang, J.Y. A model for assessing the feasibility of construction project in contributing to the attainment of sustainable development. J. Constr. Res. 2012, 30, 989-994. [CrossRef]

51. Sun, X.; Liu, X.; Li, F.; Tao, Y.; Song, Y. Comprehensive evaluation of different scale cities' sustainable development for economy, society, and ecological infrastructure in China. J. Clean. Prod. 2015. [CrossRef]

52. Zhang, X.; Wu, Y.; Skitmore, M.; Jiang, S. Sustainable infrastructure projects in balancing urban-rural development: Towards the goal of efficiency and equity. J. Clean. Prod. 2015, 107, 445-454. [CrossRef]

53. Manos, B.; Partalidou, M.; Fantozzi, F.; Arampatzis, S.; Papadopoulou, O. Agro-energy districts contributing to environmental and social sustainability in rural areas: Evaluation of a local public-private partnership scheme in Greece. Renew. Sustain. Energy Rev. 2014, 29, 85-95. [CrossRef]

54. Chang, R.D.; Zuo, J.; Soebarto, V.; Zhao, Z.Y.; Zillante, G.; Gan, X.L. Sustainability Transition of the Chinese Construction Industry: Practices and Behaviors of the Leading Construction Firms. J. Manag. Eng. 2016, 32, 05016009. [CrossRef]

55. Balkema, A.J.; Preisig, H.A.; Otterpohl, R.; Lambert, F.J.D. Indicators for the sustainability assessment of wastewater treatment systems. Urban Water 2002, 4, 153-161. [CrossRef]

56. Development, I.I.F.S. Compendium of Sustainable Development Indicator Initiatives; IISD: Geneva, Switzerland, 2006.

57. Ezeah, C.; Roberts, C.L. Analysis of barriers and success factors affecting the adoption of sustainable management of municipal solid waste in Nigeria. J. Environ. Manag. 2012, 103, 9-14. [CrossRef] [PubMed]

58. Chen, M.Q. Analysis on System Obstructions to Small Town Sustainable Development and Countermeasures in China. China Popul. Resour. Environ. 2004, 1, 60-63.

59. Qin, C.; Wang, J. On the Development of Mountain Economy of China's Western Regions: Based on Ecological Civilization. Ecol. Econ. 2012, 10, 62-71.

60. Zhou, J.; Tam, V.; Qin, Y. Gaps between Awareness and Activities on Green Construction in China: A Perspective of On-Site Personnel. Sustainability 2018, 10, 2266. [CrossRef]

61. Capwell, E.M. Theory of Planned Behavior; Springer: New York, NY, USA, 2013; pp. 179-211.

62. Ajzen, I. From Intentions to Actions: A Theory of Planned Behavior; Springer: Berlin/Heidelberg, Germany, 1985; pp. 11-39.

63. Ajzen, I. Perceived Behavioral Control, Self-Efficacy, Locus of Control, and the Theory of Planned Behavior. J. Appl. Soc. Psychol. 2002, 32, 665-683. [CrossRef]

64. Chen, C.F.; Chao, W.H. Habitual or reasoned? Using the theory of planned behavior, technology acceptance model, and habit to examine switching intentions toward public transit. Transp. Res. Part F Traffic Psychol. Behav. 2011, 14, 128-137. [CrossRef]

65. Fan, W.S.; Haung, Y.K.; Hsu, H.C.; Chen, C.C. An Analysis of the Blog-User Attitude Employing Structural Equation Modeling Combine TAM and TPB Model. In Proceedings of the International Conference on Information Technology and Management, Bucurestic, Romania, 20-23 January 2013; pp. 90-93.

66. Lin, G.; Shen, G.Q.; Sun, M.; Kelly, J. Identification of Key Performance Indicators for Measuring the Performance of Value Management Studies in Construction. J. Constr. Eng. Manag. 2011, 137, 698-706. [CrossRef]

67. Yunhi, K.; Han, H.S. Intention to pay conventional-hotel prices at a green hotel-A modification of the theory of planned behavior. J. Sustain. Tour. 2010, 18, 997-1014.

68. Ajzen, I. The theory of planned behavior, organizational behavior and human decision processes. J. Leis. Res. 1991, 50, 176-211.

69. Kan, M.P.H.; Fabrigar, L.R. Theory of Planned Behavior; Springer: Cham, Switzerland, 2017. 
70. Abrahamse, W.; Steg, L.; Gifford, R.; Vlek, C. Factors influencing car use for commuting and the intention to reduce it: A question of self-interest or morality? Transp. Res. Part F Traffic Psychol. Behav. 2009, 12, 317-324. [CrossRef]

71. Angelidou, M.; Psaltoglou, A. An empirical investigation of social innovation initiatives for sustainable urban development. Sustain. Cities Soc. 2017. [CrossRef]

72. El-Gohary, N.M.; Osman, H.; El-Diraby, T.E. Stakeholder management for public private partnerships. Int. J. Proj. Manag. 2006, 24, 595-604. [CrossRef]

73. Shah, R.; Goldstein, S.M. Use of structural equation modeling in operations management research: Looking back and forward. J. Oper. Manag. 2006, 24, 148-169. [CrossRef]

74. Shneif, M. Principles and Practice of Structural Equation Modeling; Guilford Press: New York, NY, USA, 2015.

75. Shen, W.; Xiao, W.; Wang, X. Passenger satisfaction evaluation model for Urban rail transit: A structural equation modeling based on partial least squares. Transp. Policy 2016, 46, 20-31. [CrossRef]

76. Xiong, B.; Skitmore, M.; Xia, B. A critical review of structural equation modeling applications in construction research. Autom. Constr. 2015, 49, 59-70. [CrossRef]

77. Chan, D.; Kumaraswamy, M.M. A comparative study of causes of time overrun in Hong Kong construction projects. Int. J. Proj. Manag. 1997, 15, 55-63. [CrossRef]

78. Jahangir, N.; Begum, N. The role of perceived usefulness, perceived ease of use, security and privacy, and customer attitude to engender customer adaptation in the context of electronic banking. Afr. J. Bus. Manag. 2008, 2, 32-40.

79. Jokar, N.K.; Noorhosseini, S.A.; Allahyari, M.S.; Damalas, C.A. Consumers' acceptance of medicinal herbs: An application of the technology acceptance model (TAM). J. Ethnopharmacol. 2017, 207, 203-210. [CrossRef] [PubMed]

80. Welsch, H.; Kühling, J. How Green Self Image is Related to Subjective Well-Being: Pro-Environmental Values as a Social Norm. Ecol. Econ. 2018, 149, 105-119. [CrossRef]

81. Liang, C.C.; Shiau, W.L. Moderating effect of privacy concerns and subjective norms between satisfaction and repurchase of airline e-ticket through airline-ticket vendors. Asia Pac. J. Tour. Res. 2018, 23, 1142-1159. [CrossRef]

82. Gellman, M.D.; Turner, J.R. Perceived Behavioral Control; Springer: New York, NY, USA, 2013; p. 1450.

83. de Bruijn, G.J.; Rhodes, R.E. Exploring exercise behavior, intention and habit strength relationships. Scand. J. Med. Sci. Sports 2011, 21, 482-491. [CrossRef] [PubMed]

84. Morwitz, V.G.; Fitzsimons, G.J. The Mere-Measurement Effect: Why Does Measuring Intentions Change Actual Behavior? J. Consum. Psychol. 2004, 14, 64-74.

85. Dublin. The Dublin Statement on Water and Sustainable Development. Environ. Conserv. 2017, 19, 6. [CrossRef]

86. Doloi, H.; Iyer, K.C.; Sawhney, A. Structural equation model for assessing impacts of contractor's performance on project success. Int. J. Proj. Manag. 2011, 29, 687-695. [CrossRef]

87. Fornell, C.; Larcker, D.F. Structural equation models with unobservable variables and measurement error: Algebra and statistics. J. Mark. Res. 1981, 18, 39-50. [CrossRef]

88. Bandalos, D.L. The effects of item parceling on goodness-of-fit and parameter estimate bias in structural equation modeling. Struct. Equ. Model. A Multidiscip. J. 2002, 9, 78-102. [CrossRef]

89. Meng, J.; Xue, B.; Liu, B.; Fang, N. Relationships between top managers' leadership and infrastructure sustainability. Eng. Constr. Arch. Manag. 2015, 22, 692-714. [CrossRef]

90. O'Rourke, N.; Hatcher, L. A Step-By-Step Approach to Using SAS System for Factor Analysis and Structural Equation Modeling. Int. Stat. Rev. 2013, 83, 325-326.

91. Bacon, D.R.; Sauer, P.L.; Young, M. Composite reliability in structural equations modeling. Educ. Psychol. Meas. 1995, 55, 394-406. [CrossRef]

92. Gloukhovtsev, A. Don't give me attitude: Can perceptions of social norms, behavioral control and moral intensity help bridge the attitude-behavior gap in ethical consumer behavior? J. Microbiol. Methods 2014, 23, 169-182.

93. Johe, M.H.; Bhullar, N. To buy or not to buy: The roles of self-identity, attitudes, perceived behavioral control and norms in organic consumerism. Ecol. Econ. 2016, 128, 99-105. [CrossRef]

(C) 2018 by the authors. Licensee MDPI, Basel, Switzerland. This article is an open access article distributed under the terms and conditions of the Creative Commons Attribution (CC BY) license (http://creativecommons.org/licenses/by/4.0/). 